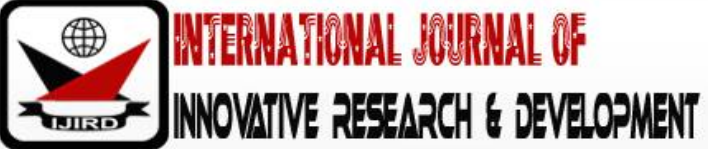

ISSN 2278-0211 (Online)

\section{Persistent Insecurity in Nigeria: Need for Respect for Human Life}

\author{
Dr. Ignatius Nnaemeka Onwuatuegwu \\ Lecturer, Department of Philosophy, \\ Nnamdi Azikiwe University, Awka, Nigeria
}

\begin{abstract}
:
Nigeria is the most populous country in Africa, and this exposes them to security challenges that are affecting every sector of the economy as well as the loss of value to human lives and properties. Security studies are very crucial at every point in time in the life of a nation, and that is why due consideration is given to anything that borders on security in the nation. Insecurity, being a significant hit on development, is also not suitable for the effective running of the society, and so it has to be tackled. This paper, therefore, examines the persistent insecurity in Nigeria and the need for human life. Human lives are so precious that it was adequately catered for in the constitution. The constitution covers many rights of the citizens. The paper examined the concept of security, insecurity, human rights, origin and incidence of insecurity in Nigeria, insecurity and threats to human lives, causes, consequences and solutions to insecurity. The study recommended that the government should adequately cater to the needs of its citizens in terms of ensuring maximum security and provision of employment amidst others.
\end{abstract}

Keywords: Insecurity, security, human rights

\section{Introduction}

Insecurity in Nigeria has reached the level of danger that it influences negatively every area of human life. It is a subject that is not only peculiar to Nigeria alone, but it is a significant challenge in some countries around the globe. Insecurity as a social menace has eaten deep into the fabrics of the economy that every sector of human lives is affected, and this does not leave out a threat to human life. Insecurity is generally defined as the absence of resistance to or shields from threat, harm, peaceful co-existence and inclusive development (Obarisiagbon \& Akintoye, 2019). Achumba, Ighomereho \& Akpor-Robaro (2013) viewed insecurity as the opposite of security that influences the life and existence of human. Generally, it is a state of being subject to fear, threat, danger, molestation, intimidation, harassment, among others (Obarisiagbon \& Akintoye, 2019).

Insecurity has made trade and commerce to suffer much, and this had made lives unbearable for Nigerians because their lives and properties are no longer safe; it has also affected their means of livelihood because they can no longer carry out economic activities successfully for fear of unsecured environment. Insecurity has also caused a drop in the revenue of government as businesses that are supposed to pay revenues are no longer fully operational. It is also observed that the social life is being hampered in areas that are porous in terms of security and this alone has made many to run for the sanity and sanctity of their lives as insecurity no longer guarantees their safety; they had now migrated for fear of being killed, kidnapped or maimed. The challenge of insecurity in Nigeria can be traced to what Adejumo (2011) viewed as the careless behaviour of the Nigerian government which is supposed to respect the Section 12 (2) (b) of the Nigerian Constitution (1999).

Bankong-Obi (2011) stated that the situation will persist and might deteriorate because the law enforcement agencies seem not to be prepared for the challenges. Adegbami (2013) noted that Nigerians had lost total trust in law enforcement agents when it comes to protecting their lives and properties because of their inefficiency due to inadequate modern weapons and communication gadgets. In the light of preceding, the government is meant to guide the lives and properties of its citizens, making use of the available security agencies constitutionally recognized for maintaining law and order.

Human lives are sacrosanct that they are adequately catered for in the constitution, but it is very glaring that these rights have been violated in several ways. Amnesty International (2018) stated that significant portions of the Nigerian constitution, especially the clauses that have to do with human and international treaties at the regional and the global levels had not been respected.

Despite the provision of Section 14 (2) (1), insecurity and criminal activities like ritual killings, terrorism, kidnapping, and pipeline vandalism have continued to make the news in Nigeria. The surge of insecurity has affected the economy by making commercial activities paralyzed. The persistent insecurity challenges in Nigeria and the need for the respect of human lives is the concern of this paper 


\section{The Concept of Security and Insecurity}

Security is one of the basic needs of humans. Where there is no security in a society, the population would be prone to attacks from enemies. Insecurity can be defined as the state of being insecure or unsafe. The state is responding to providing security for members of the society (Awojobi, 2014). Insecurity which has numerous definitions, is simply referred to a situation whereby a place, country, nation, town or community is not safe or secured. It is the direct opposite of security. It is very right to talk about security as opined by different authors to get the root meaning of insecurity effectively.

Omede (2012) considered security as a changing situation that refers to the ability of the State/Country to get rid of threats to its values and interests. Onifade (2013) defined security as the condition of putting in place machinery for the protection of people, information and properties against dangerous influences. It refers to a situation where people within a given space natural or otherwise move freely without threats to their lives or properties.

It is a situation whereby people can comfortably sleep without fear. When individuals are protected from aggressions and attacks that make them maximize their economic and social development potentials, then we say they are secured and if otherwise happen and then we call the situation insecurity. Ewetan and Urhie (2014) opined that security is termed as the absence of threats to human life, peaceful living, co-existence, stability, national integration, political and socio-economic goals of the country. Nweke and Nwachukwu (2014) stated that to be secured is to have a reasonable level of predictions about security operations at various levels of the social system all over the globe.

Insecurity is just the very opposite of what has been defined as security. Insecurity, like security, is viewed in several ways. It was viewed by some group of people as the absence of safety or presence of danger, hazard, lack of confidence, trouble, lack of protection and unsafe living environment (Achumba, Ighomereho \& Akpan-Robaro, 2013). Insecurity as a grave menace can lead to the loss of confidence, fearful tendencies, oppression, depression, loss of focus amidst other negative occurrences in society.

\section{Conceptualizing Human Right}

Human right is a fundamental subject that has a direct linkage with security. It is vital for any government that values the right of their citizen to consider the security of their citizen seriously. It is a violation of rights not to cater and care for the properties and lives of the citizens. The existence of a human right in Nigeria can be traced from the beginning of colonial regulation. The traditional society recognized human right and fundamental freedoms in Nigeria (Nwafor \& Ogbuka, 2019). The human right is made up of the following outlined values; freedom of thought, speech, belief and association, kin and clan membership, right to family, right to enjoy the personal property and right to engage in the governance of affairs of the society (Agwunobi \& Onyedolapo, 2012).

Akhaine and Chizea (2011) stated that the 1979 and the 1999 constitutions improved by making provisions for a bill of rights. Chapter II that contains the fundamental objectives and directive principles of state policy also recognized economic, social and cultural rights. The inclusion of human rights requirements in the constitutions was aimed at creating a society which respects and protects the political freedom as well as the social and economic comfort of Nigerians. However, with the assurance of fundamental rights and freedoms in the Nigerian constitutions since 1960, the country has experienced military disruptions. This affected the upgrade and defence of values and fundamental rights in Nigeria (Adesupo, 2013).

Prior democracy in Nigeria in 1999, the military government does not respect human rights of the citizens, though with few exceptions. This happened between November 1994 and June 1998. This worst scenario about human rights under the military government led to the placement of the nation on seclusion for five years by the United Nations Commission on Human Rights (Nwafor \& Ogbuka, 2019). Nigerians led by human rights civil society groups involved the military to ensure a better society that is ruled by constitutionalism, the rule of law, social justice and respect for human rights (Adetoro \& Omiyefa, 2014). This finally led to the constitution of the Federal Republic of Nigeria, 1999 and the enthronement of democracy and democratic institutions in 1999.

Human rights, according to Abbah (2013) are not just a collection of formal norms but are fundamentally political, social, economic, juridical, as well as moral, cultural and philosophical circumstances which uphold the value of man and his inherent self-esteem.

\section{Origin and Incidence of Insecurity Crisis in Nigeria}

Nigeria is a blessed country with both human and natural resources. With this inherent greatness, it is still being observed that Nigeria and her citizens are still being ravaged with security challenges like killing, armed robbery and abuse of human lives and properties which has affected the smooth running of the economy. The security challenges ravaging the country can be traced to the post-civil war incidences and enthronement of the military that led to the importation and use of arms and ammunitions (Ewetan \& Urhie, 2014).

Ewetan and Urhie (2014) stated that after the civil war, arms possessed by civilians and ex-military men were now applied in carrying out criminal activities. With the increase and flow of arms, the majority of the citizen lost their jobs due to the war, and this makes many to switch over to criminal activities in order to survive. There was an increase in crimes like kidnapping in the 1990s, and the Niger Delta militants used it as a way of protesting against the exploitation and environmental degradation of their community. The Niger Delta region, which is known as the origin of Nigeria's wealth suffers amid plenty. The deprivation of the Niger Delta region made the youth to come up with various militant groups involved in kidnapping, blasting of oil wells. These situations led to security crisis which the Federal government tried to bring under control between May 2007 and May 2015 (Obarisiagbon \& Akintoye, 2019). 
In the South-East region as well, there is the agitation for a Biafra State which was pioneered and muted by the late Col. Emeka Odumegwu Ojukwu; this later resulted into the activities of MASSOB and IPOB. These uproars have resulted in security challenges in the south-east, and alleged marginalization and partial development embarked upon by the federal administration. In the Middle-belt of North Central Zone, insecurity is prevalent in the zone. In Plateau State particularly, the conflict between the Hausa-Fulani and the Birom people led to the death of hundreds of people while in Benue State, Governor Samuel Ortom is not having a pleasant time with the conflict between the Fulani herdsmen and the local people and this has resulted into the death of many and displacements of many from their villages. The North-East Zone of Nigeria is not left out of the security challenges, Boko Haram. Edo State has also been affected by kidnapping, and some of its communities have been attacked by the Fulani herdsmen who continually rape women and girls, kill both old and young people and as well destroy their farm products (Obarisiagbon \& Akintoye, 2019).

\section{Insecurity and Threats to Human life}

Mohammed Yusuf established the Boko Haram sect in Maiduguri, Borno State, in the North-East region of the country. He opined that the Nigerian state is corrupt and therefore called for the creation of an Islamic caliphate (International Crisis Group, 2014). The activities of the sect had led to bombings, kidnapping and suicidal attacks that also led to the destruction of properties and lives. They have a sole aim of disrupting constituted authority in order to enthrone ideological, political or religious agenda that affects the security apparatus of the nation (Omilusi, 2016). The continued attacks from July 26th, 2009 had led to a reduction in foreign direct investment and socio-economic activities in the NorthEast region of Nigeria; there is also the reduction in the gross domestic product as a result of haphazard investment opportunities, negative influences on the standard of living in Yobe, Borno and Adamawa States (Ibrahim, 2015). The increased rate of violence and killing of thousands and displacement of over 2.3 million from their houses placed Nigeria as the 3rd most terrorized country in the world (Sahara Reporters, 2018).

Chris (2012) stated that the major focus of Nigeria's national security policy is the preservation of the safety of citizens at home and outside the shores of the country with the protection of the country as well. Every state has the duty of securing its territory and protecting the people from attacks and violence. There are many cases of threats and insecurity of lives in the nation, so this keeps affecting the human lives. It is therefore essential for the root causes of the challenges to be tackled so that the sanity of the human lives can be preserved, but if nothing is being done, there would be a continual violation of human rights and the threats to lives and properties would continue unabated.

\section{Causes of Insecurity}

The scourge of insecurity is caused by many factors which are discussed as follows:

\subsection{Bad Governance}

Governance has been a significant problem in Nigeria, and the effects are felt in the way the security of lives and properties are being maintained. Government's main function is to protect lives and properties of its citizens by providing water, electricity, good road network, standard education and general infrastructure; many governments due to bad governance had drifted away from this purpose to pursue other selfish desires. This had worsened the security challenges in the society.

\subsection{Economic Imbalance and Marginalization}

Our economy is no longer viable as a result of looting and other harsh economic policies that have placed riches in the hands of few and left others poor. The people who can no longer tolerate these imbalances resorted to violence, robbery, terrorism and other social vices that become threats to human lives and properties. These economic imbalances as well lead to the marginalization of some regions at the expense of some other regions that had led to the establishment of different sects terrorizing the people causing civil unrest and threats to human rights, lives and properties.

\subsection{Ethnic/Religious Intolerance}

This is another major cause of insecurity in Nigeria. Nigeria is made up of many ethnic and religious groups. This alone had led to intolerance of many occasions which had led to one form of violence or the other. When there is violence as a result of ethnic or religious crises, the peace and stability of the country are threatened, lives and properties are destroyed.

\subsection{Poor/Weak Security Apparatus}

The security outfit in Nigeria does not measure up to standard in terms of personnel and machinery. This makes our security sector to be porous and not being able to curtail the challenges in the country. The personnel in the security sector are not adequately catered for in terms of remuneration and promotion, and this makes them unwilling to do the job with maximum efforts.

\subsection{Loss of Traditional Value and Moral System}

In Nigeria, the values we held sacred have been ignored, and this is affecting the protection of human lives and properties. The lives and values that used to be respected no longer mean anything to us in the country and this is evident in the way we treat one another and also evident in the way we respect values like respect for elders, leaders, laws and constitution that governs the country. The values once held for life, the dignity of hard work, honesty and integrity and hospitality had been eroded, which makes it possible for insecurity to continue unabated. 


\subsection{Porous Borders and Arms Proliferation}

The porous nature of the Nigerian borders has made it possible for the influx of people from other countries like Niger, Chad, Benin, Mali and Niamey into the country with their unchecked lifestyles (Adeola \& Oluyemi, 2012).

\subsection{Unemployment/Poverty}

Many of the citizens are not gainfully employed and as such cannot cater to their basic needs of life like clothing, shelter and feeding. Unemployment makes many to go into poverty and as such looks for alternative means to survive. These means that they come up with are not healthy for the society as they go into kidnapping, killing, terrorism and armed robbery to survive and this makes the value for human lives and properties to be threatened. The presence of poverty with attendant lack of food makes the poor to result in violence and other vices that impact negatively on the security of the country (Egbefo \& Salihu, 2014).

\section{Consequences of Insecurity}

Insecurity has numerous effects on the country's wellbeing in terms of physical, social and economic. When a country is being ravaged by insecurity, it leads to underdevelopment because most of the drives to drive development would be hindered by the incessant attack on the structures of the country. It should be known that development does not thrive in a country with security challenges like what is obtainable in Nigeria where regions of the country are being battered with issues of insurgency, kidnapping, killing and armed robbery in the highest order. Development can never thrive in a situation where there are instability, fear, threats and reduced value for human lives and properties.

Partners or investors that have the tendency of investing in a country studies the developmental potential of the country to see if it is viable for investment and any country that shows less potential for investment to yield is left for a better country, and this makes the cycle of underdevelopment to continue. Most of these criteria could be lack of security outfit to ensure that investments are rightly protected.

Insecurity would also result in many vices like killing, kidnapping, drug addiction which invariably results in poverty which also hampers the growth and development of the society. Most of these challenges are so worse to the point that security personnel were also abducted. This is portraying that the country is not a safe haven for the citizens to thrive.

\section{Solutions to Insecurity}

Some of the root causes of insecurity have been discussed earlier now. It is therefore important that solutions are provided to the causes above and as well look into some of the other solutions outlined below:

\subsection{Value/Moral Education}

We must go back to the values we held sacrosanct in the time past, and this can be effectively tackled through the introduction of value/moral education into our curriculum. It is not just enough to include the instruction in our curriculum, but there should be effective monitoring to ensure that the right things are being done in achieving the desired objectives. In moral/value education, children must be guided on how to uphold respect for life, dignity, honesty, fairness, hard work and respect for leaders. They have to be guided on the need to avoid criminality, violence, greed and terrorism.

\subsection{Technical/Career Education}

It is also imperative that priority should be given to our technical and career education. This would reduce the incidence of unemployment drastically. When the majority of the people are vast and knowledgeable about their vocation, they would be less concerned in breaching the peace of the society, which makes everyone to move without being scared of security challenges. The introduction of technical education would lead to the production of graduates in diverse fields like auto-mechanics, auto-electricians and computer engineers, building technologists, house electricians and professionals in fashion designing, carpentry and woodworks.

\subsection{Development of our Security Apparatus}

Our security sector must be given adequate attention if insecurity must be tackled in Nigeria. There should be overhauling of the personnel in the security sector as many of them are not worthy of their calling in terms of character and dedication to duty. They need to be adequately trained to measure up to the current standard worthy of being with global best practices. In terms of machinery, our security outfit should be equipped with modern-day facilities that would enable them to tackle insurgencies in the country.

\subsection{Rule of Law}

This is another sector that would tackle the menace of insecurity in the nation. The rule of law should be respected as this would make marginalization to be a thing of the past because equality before the law would now be the order of the day. The law that has the right of humans should be effectively upheld in order to value human lives and as well as valuable properties and restore sanity to the country. It is, therefore, necessary to make everyone obey the law.

\subsection{Good Governance}

This is another important area that determines the success or failure of security endeavours in the country. The bulk of what is being discussed is based on the premise of governance. When countries have good leaders, they will ensure that human rights are upheld and also makes it possible for lives to be protected. 


\section{Conclusion and Recommendation}

This study examined the persistent insecurity in Nigeria and the need for the respect of human life. Security is needed for the growth, peace, progress, development and political stability of any society and anything short of this led to insecurity. The level of insecurity in Nigeria is so alarming that it has affected the economy of the nation. It has also affected human lives as a result of the violation of the rights that protect humans. This invariably shows that more work needs to be done to restore the sanity of the country. It is imperative having discussed some of the challenges, consequences and possible solutions to insecurity. There is a need for the government and citizens of the country to help in combating insecurity at all quarters. It is also crucial that the government do not politicize every effort aimed at solving security challenges in society. It is also significant for the government of Nigeria to outline ways of tackling insecurity and its causes. There is also a need for good governance that takes care of the rule of law, education, employment and concerned about the welfare of the citizens. It is until when these and many more are being done that peace, respect and value for human lives would be restored.

\section{References}

i. $\quad$ Abbah, T. (2013). Fulani/farmers clashes claim 300 lives in 5 months. Sunday Trust, May 26th.

ii. Achumba 0. Ighomereho and Akpor-Robaro (2013). Security challenges in Nigeria and the implications for business activities and sustainable development. Journal of Economic and Sustainable Development, 4 (2): 79 - 99.

iii. Adegbami, A. (2013). Insecurity: A threat to human existence and economic development. Nigeria Public Policy and Administration Research, 3 (6): 15-28.

iv. Adejumo, A. (2011). The problems and challenges of insecurity in Nigeria (online). Available http://newsdiaryonline. com/tok_securityhtml (April 12, 2020).

v. Adesupo, P. A. (2013). The roles of the church in curbing rape in Nigerian society. Lagos: NASRED Publication.

vi. Adetoro, R. A. and Omiyefa, M. O. (2014). Challenges of human rights abuses in Nigerian democratic governance which way forward? Journal of Social Economics Research, 1 (5): 87-96

vii. Adeola, G. L. and Oluyemi, F. (2012). The political and security implications of cross border migration between Nigeria and her francophone neighbours, Internal Journal of Social Science Tomorrow, 1 (3).

viii. Agwunobi, C. J. and Onyedolapo, B. D. (2012). Human rights and diplomacy. School of Arts and social science course Guide on Human Rights and Diplomacy (PCR 819). National Open University of Nigeria (NOUN).

ix. Akhaine, S. O. and Chizea, B. U. (2011). State of human rights in Nigeria - CENCOD annual report. Abuja: Centre for Constitutionalism and Demilitarization.

x. Amnesty International (2018). Nigeria: Still no accountability for human rights violations. Amnesty International submission for the UN Universal Periodic Review, 31 ${ }^{\text {st }}$ session of the UPR Working Group, November 2018.

xi. Awojobi, O. N. (2014). Poverty and insecurity in Nigerian democratic dispensation. International Journal of Innovative Research and Development, 3 (6): 357-366.

xii. Banking-Obi, N. (2012). Remorseless killers. The News, December 17th available at http://pmnewsnigeria.com/ 2012/12/10remorselesskillers/

xiii. Chris, I. (2012). Security challenges and economy of the Nigerian State. American International Journal of Contemporary Research, 2 (5).

xiv. Egbefo, D. O. and Salihu, H. A. (2014). Internal security crisis in Nigeria: Causes, types, effects and solutions. Internal Journal of Arts and Humanities (IJAH), 3 (4).

xv. Ewetan, O. O. and Ese, U. (2014). Insecurity and socio-economic development in Nigeria, Journal of Sustainable Development Studies, $\mathbf{5}(1)$.

xvi. Ewetan, O. O. and Urhie, E. (2014). Insecurity and socio-economic development in Nigeria. Journal of Sustainable Development Studies, 5 (1): 40 - 63.

xvii. Ibrahim, K. (2015). Boko Haram terrorism in Nigeria: Historical and political-economic exploration. Ile-Ife: Revolutionary Socialist Publication

xviii. International Crisis Group (ICG). (2014). Curbing violence in Nigeria (II): The Boko Haram insurgency. Africa Report No. 216. Brussels: ICG. April 3rd

xix. Nwafor, A. O. and Ogbuka, I. M. (2019). Human rights practices and security agencies in North East of Nigeria: An appraisal 2010-2018. International Journal of Academic Research in Public Policy and Governance, 6 (1): 28-49.

xx. Nweke, P. O. and Nwachukwu, T. S. (2014). National security issues and challenges in Nigeria: Which way forward? International Journal of Youth Empowerment and Entrepreneurship Development, 1 (1).

xxi. Obarisiagbon, E. I. and Akintoye, E. O. (2019). Insecurity crisis in Nigeria: The law enforcement agents a panacea? Journal of Sociology and Social Work, 7 (1): 44-51.

xxii. Omede, J. (2012). Reformatting Nigerian secondary and post-secondary education to meet unemployment and security challenges in Nigeria in the 21st century. Research Journal in Organizational Psychology and Educational Studies (RJOPES). Available at http://www.emergingresource.org

xxiii. Omilusi, M. (2016). Insurgency and terrorism in Nigeria: Perspectives, phases and consequences. Ado-Ekiti: Olugbenga Press

xxiv. Onifade, C. (2013). Addressing the insecurity challenge in Nigeria: The imperative of moral values and virtue ethics. Global Journal of Human Social Science Political Science, 13 (2).

xxv. SaharaReporter (2018). Nigeria ranked the 3rd most terrorized global nation available: http://saharareporters.com/2018/12/07/nigeria-ranked-3rd-most-terrorised-global-nation Dec. 07, 2018 